\title{
$1-2-75$ 㽬部外賃による頚鳴に就ての臨床的観察
}

\section{吅可村進市 大藤周彦(日医大)}

緒言

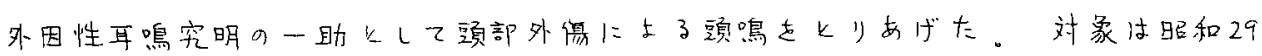
年4 月以降の1701例であつた。之等の成績を昭和41年表表の頭部外偒による耳鳴 と比较檢討した。

\section{成績}

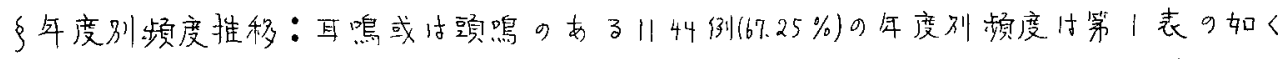
で, 昭和2 9 年上り33年3 月迄は50\%代, 33 年4 月上り 38 年3 月迄は70\%代, 38 年 4 月上り42年3 月迄は80\%代飞漸增の倾何にあり注目士水た。

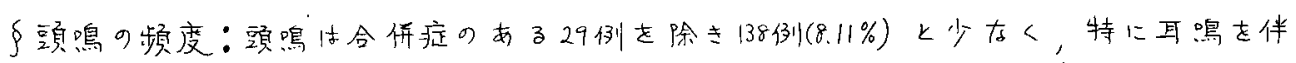

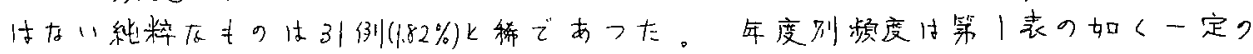
候向は中うれなかつた。䫓鸣火関係した丰のは141例で內3例(2.13\%)は消失し，耳 鳴火合併した的の107例(75.89\%)，頭鳴單独31例(21.98\%)であつた。消夫率を比較し 乙2 3 k, 耳鳴では1133例中消失176例であり), 二9内一侧栈存33例を除く 143 例(12.

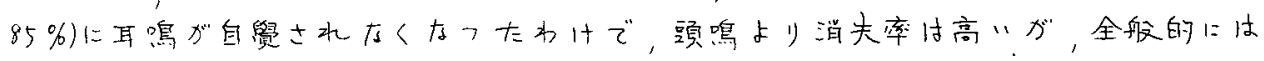
低“。治療の行わ水た場合多“が，明かに治効によるく認めら水るキのは少 なく、氛腾字、脂動撮、星状种程節遮断等により消失した例丰おつた。

乌頭鸹の性狀：消失例を除き常在性は80例(57.97\%)で半介上上を占め，間歇性は54例 $(39.13 \%) k$ 約 $\frac{1}{3}$ ，不明 4 例 $(2.90 \%)$ であた。耳鳴では常在性678耳(59.84\%)，間歇性455 耳 $(40.16 \%)$ で大差はなかつた。

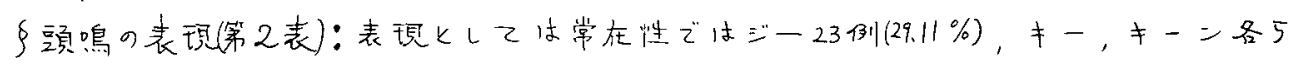

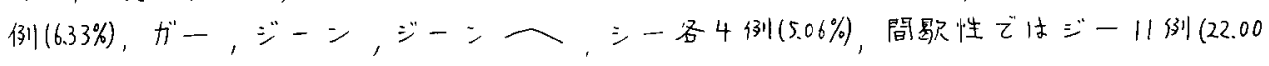

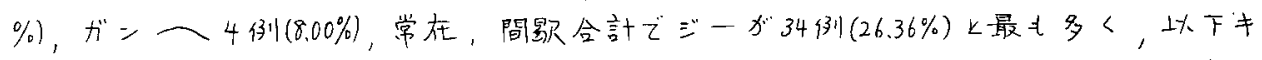
一丁例, キーン, ガ一各6 例, ガン人, シー各5 例であった。耳鳴では常在

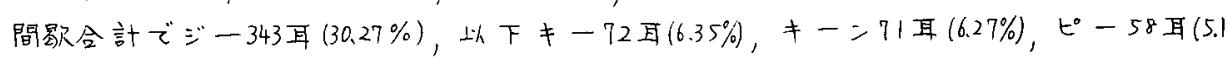

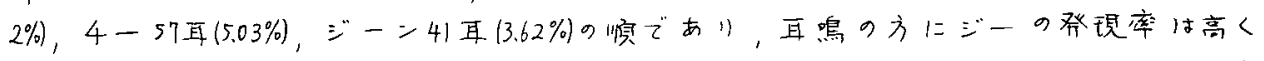

又顽鳴，耳鳴共に常在性のうにジ一の频度は高かった。

脉音性(第3 表)

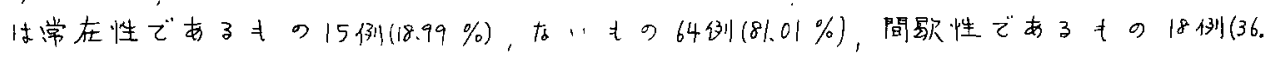

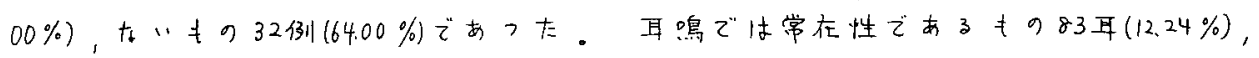
間歇性であるもの89耳 $(19.56 \%)$ で，顽鳴，耳鴊飞もに間歇性に脉音の頻度は高かつ

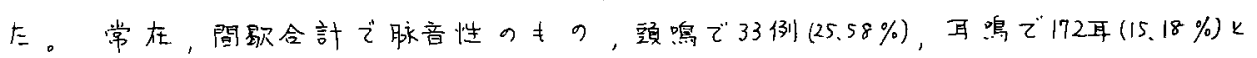
顽鳴の方に高率で，弓の性状推定の参考になるのではないかと考えられた。 §耳鳴飞の類似性：常在性到鸣80例中耳鳴のない16 例 $(20.00 \%)$ ，不明2例を除き，同

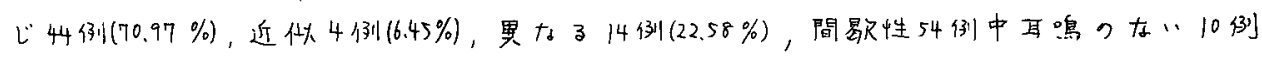
$(18.52 \%)$ ，不明5例を除き，同じ17例 (43.59\%)，近似了例 $(7.69 \%)$ ，異古子 19 例(48.72\%)で 数似性は常在性に强かつた。常在, 間弱合計で同じ61例(60.40\%), 近似7 例 (6.93\%) 
異なる33例(32.67\%)で，67 \%に類似していた。

$\oint$ 頭鴽の颣什周波数(第4表): 顽鳴の数似周波数は常在性 で高音域 $80.88 \%$ ，中音域 7.3 $5 \%$ ，低音域 $11.77 \%$ ，間歌性で 高音域 $77.275 \%$ ，中音域13.635 $\%$ ，低音域 $9.09 \%$ ，常在，間 歇合計兗音域 $80.00 \%$ ，中 音域 $8.89 \%$ ，低音域 $11.11 \%$ であ つた。耳鳴では常在性で 高音域 $75.22 \%$ ，中音域 13.42 $\%$ ，代音域 $11.36 \%$ ，間歇性 で高音域 $59.34 \%$ ，中音域 14 . $07 \%$ ，伯音域 $26.59 \%$ ，常在 間歌合計で高音域 $68.84 \%$ 中音域 $13.68 \%$ ，低音域17 $48 \%$ であり，领嘄の方に高 音域策中倾向が强い。

結論

上上到部外稘に上る頭鳴の

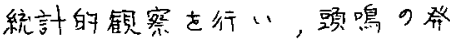
瑅率は小士く，消失例北榅く 稀である等の新知見を得たが 特に顽鳴では neurotic factor の除去に細心の注意を㭋はな け扎ば存らない。このよう に耳鳴の統計的镇察を行なつ 乙いるのは; 耳鳴湌查が聴 翼，前庭栈能检查に比し貪弱 であるからにほかならない。

然儿实駺的或は病理解剖悬 的根㧻のない耳鳴では症例の 詳細な長期穓察七臨床检查成 綨の集㯖による上外过展はな <，原因が比较的明かな対象 にめぐ夫水ているので，更に 穓察をつでけ乙行きたいと考 元2“3.
第|表頭鳴，耳鳴の年度别颎度推移

\begin{tabular}{|c|c|c|c|c|}
\hline & \multicolumn{2}{|c|}{ 耳鳴あるいは顽鳴 } & \multirow{2}{*}{ 䫏鳴のある例 } & \multirow{2}{*}{ 計 } \\
\hline & 女子例 & ない例 & & \\
\hline $2 \begin{array}{lllll}2 & 30 & 30 & 31\end{array}$ & $132 \quad(56.41 \%)$ & $102(43.59 \%)$ & $13(5.56 \%)$ & 234 \\
\hline 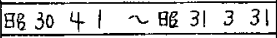 & $(53.54 \%)$ & $92 \quad(46.46 \%)$ & $14 \quad(7.07 \%)$ & 198 \\
\hline 几 昭 32331 & $(54.80 \%)$ & $\{45,20 \%)$ & $(10,17 \%)$ & 177 \\
\hline$\approx$ 昭 $33 \quad 3 \quad 31$ & $119 \quad(58.91 \%)$ & $(41.09 \%)$ & $(6.44 \%)$ & 202 \\
\hline$\sim$ 昭 34331 & $127(71.75 \%$ & $128.25 \% 1$ & $(14.69 \%)$ & 177 \\
\hline$\sim 08353 \quad 31$ & $172.50 \% 1$ & $(27.50 \%)$ & $(6.67 \%)$ & 120 \\
\hline$\sim 8636 \quad 3 \quad 31$ & $(80.68 \%)$ & $(19.32 \%)$ & $(6.82 \%)$ & 88 \\
\hline$\sim$ 昭 $373 \quad 31$ & $(75.44 \%)$ & $14 \quad(24.56 \%)$ & $(\mid 0.53 \%)$ & 57 \\
\hline 28838331 & $175.71 \%$ & $(24.29 \%)$ & $(4.29 \%)$ & 70 \\
\hline$\sim$ 昭39331 & $(81.67 \%)$ & $(18.33 \%)$ & $7 \% !$ & 60 \\
\hline$\theta_{2} 394 \quad$ I 2 服 40331 & $(81.48 \%)$ & $(18.52 \%)$ & $(11.11 \%)$ & 81 \\
\hline $\begin{array}{lllllll}8 日_{2} & 40 & 4 & 1 & 2\end{array}$ & $177.14 \% 1$ & $122.86 \% 1$ & $(1.43 \%)$ & 70 \\
\hline $864141 \sim 8 B_{2} 42331$ & $77 \quad 180.21 \% 1$ & $(19,79 \%)$ & $110.42 \%$ & 96 \\
\hline 昭4241 二 & $63 \quad 188.73 \% 1$ & $(11.27 \%)$ & $4 \quad(5.63 \%)$ & 71 \\
\hline & $144(67.25 \%)$ & $557 \quad(32.75 \%)$ & $138(8.11 \%)$ & 170 \\
\hline
\end{tabular}

第2表頭鳴，耳鳴っ表現

\begin{tabular}{|c|c|c|c|c|c|c|c|}
\hline \multicolumn{3}{|c|}{ 頭 } & 窎 & \multicolumn{4}{|c|}{ 鳴 } \\
\hline 表 現 & 常在性 & 䦭歇性 & 言十 & 表 現 & 常在性 & 間易是性 & 言十 \\
\hline ジ- & 23 & 11 & $34(26.36 \%$ & 㳻- & 239 & 104 & $343(30.27 \%)$ \\
\hline$\neq-$ & 5 & 2 & $7(5.43 \%)$ & $\neq-$ & 51 & 21 & $72(6.35 \%)$ \\
\hline 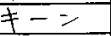 & 5 & 1 & $6(4.65 \%)$ & $¥ ー ン$ & 48 & 23 & $71(6.27 \%)$ \\
\hline$H^{\prime}-$ & 4 & 2 & $6(4.65 \%)$ & $t^{0}-$ & 32 & 26 & $58(5.12 \%)$ \\
\hline ガン人 & 1 & 4 & $5(3.88 \%)$ & $4-$ & 33 & 24 & $57(5.03 \%)$ \\
\hline$\equiv<-$ & 4 & 1 & $513.88 \%$ & ジーン & 22 & 19 & $41(3.62 \%)$ \\
\hline ガーン & 2 & 2 & $4(3.10 \%)$ & ゴー- & 10 & 24 & $34(3.00 \%)$ \\
\hline ジーン & 4 & 0 & $4(3.10 \%)$ & ガー & 13 & 19 & $32(2.82 \%)$ \\
\hline$\dot{シ}$ ジーン人 & $\frac{1}{4}$ & 0 & $4(3.10 \%)$ & $\equiv \because-1$ & 19 & 12 & $3(12.74 \%)$ \\
\hline$\Xi^{\prime}-\frown$ & 3 & 1 & $4(3.10 \%)$ & $7 "-$ & 9 & 17 & $2612.29 \%$ \\
\hline$E^{\circ}-$ & 2 & 2 & $4(3.10 \%)$ & $\equiv-$ & 21 & 4 & $25(2.21 \%)$ \\
\hline $4-$ & 3 & 0 & $3(2.33 \%)$ & $x-2$ & 12 & 12 & $24(2.12 \%)$ \\
\hline 略各 & 19 & 24 & 43 & 用各 & 169 & 150 & 319 \\
\hline 言十 & 79 & 50 & 129 & 計 & 678 & 455 & 1133 \\
\hline
\end{tabular}

第3表顽鳴，耳鳴の脉音性の有無

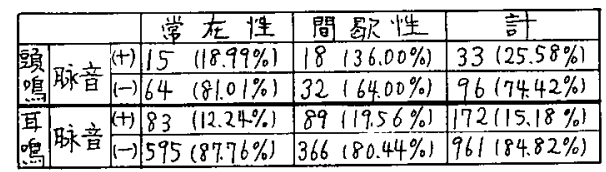

第 4 表 頭鳴，耳鳴の類似周波数

\begin{tabular}{|c|c|c|c|c|c|c|}
\hline & & 頭 & 鳴 & & & 鳴 \\
\hline & 常在性 & 鉿歇性 & 計 & 常在性 & 間歇性 & 計 \\
\hline 000 & 10 & 2 & $818.89 \%$ & 59 & 37 & $96(8.47 \%)$ \\
\hline 000 & 19 & \begin{tabular}{|l|l}
5 & 17 \\
1
\end{tabular} & $2426.67 \%) 72$ & $\frac{153}{113} 510$ & \begin{tabular}{l|l}
83 & 270
\end{tabular} & $\left.\frac{236(20,83 \%}{232(120390}\right) 780$ \\
\hline 000 & 14 (14) $(80.88 \%)$ & $6 \mid 177.275 \%$ & $\frac{2022.222 \%}{\pi 1778 \%} \mid(80,00 \%$ & $\frac{\mid 163)}{53}(75.22 \%)$ & & $\left.\frac{23 \mid 120.34 \%}{900794 \%}\right)(68.84 \%$ \\
\hline$\frac{000}{000}$ & $\left(\frac{0}{10}\right)$ & 3 & $\mid 3(14.44 \%)$ & $\frac{70}{82}$ & $\frac{114}{45}$ & $\frac{70(1.4)(2)}{127(11.21 \%)}$ \\
\hline 000 & & & $2(222 \%$ & & 27] & $11 \%$ \\
\hline 000 & 5 & 0 & 0 & 2391 & 13 & $3613.18 \% 15$ \\
\hline 500 & & & $313.335 \%)(8$ & $12](13.42$ & 15 & $27(2.38 \%)(13.66$ \\
\hline 000 & 3 & $\overrightarrow{0}$ & $3(3.335 \%)$ & 16 & & $25(2.21 \%$ \\
\hline 800 & & & $11.11 \%$ & & & $16(1.41 \%)$ \\
\hline 500 & & $\begin{array}{ll}0 & 2 \\
& \end{array}$ & $111.11 \%$ & (17) 77 & 20121 & \begin{tabular}{|l|l|}
$37(3.27 \%)$ & 198
\end{tabular} \\
\hline 250 & $I(11.77 \%)$ & 5 & $111.11 \%)(11.11 \%)$ & 11 $(11.36 \%$ & $30(26.59 \%)$ & $41(3.62 \%) \cup 7$. \\
\hline 125 & $\frac{6}{6}$ & & & $\frac{42}{I}$ & (62) & $1049.18 \%$ \\
\hline 明 & 12 & 32 & 44 & & & \\
\hline+ & & & & & to. & \\
\hline
\end{tabular}

